\title{
GEODINAMIC REGIME OF KIMBERLITE MAGMATISM MANIFISTATIONS ON THE SIBERIAN PLATFORM.
}

\author{
Shpount, B.R. \\ Central Research Institute of Geological Prospecting for Base and Precious Metals, TsNIGRI, \\ Varshavskoye Shosse, 129B, Moscow 113545, USSR.
}

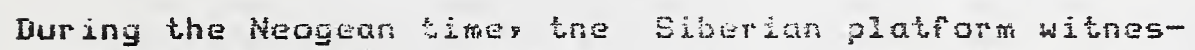
sed numerous recurrent stages of thaghtic reastivation ma-

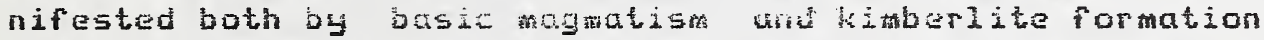
The typical property of duese seactivation stages was shat basic magmatism in each cycie was $15-20$ ha $y$. younger as compared to the kimberlite formation flare-tps.

The riftogenic bajic tagalis ist wis manifested to different scale in the Fiphean. Vendian Midale and Late Faleozoic time. In the Late Falsozoic-Early hezozoic it occurred in the geodynamic environtiten of tispersed spreading resulting in tha fortation of wapp syteclises. In the Middle and Late Mezozoic ard in Eally Cenozoic the magnatism was confined to zones of incompleze rifting. The kimberlite magmatism marifestations"echeedeach flare-up of basic astivits while the kimberlite formation was associated both with the inverse divelopment stages in paleorif: systems and epochs of reyional gaps in the platfor cover accumulation.

Feconstruttion of puleorifi systems of dif has shown that riftogenic strutcures fieqenty inherit each other"s trend.The trend of the koryest and depest Late Frecambrtan and hidde Faieczoil ripugenit depressions was inherited from the protorift bhroughs originated in the late

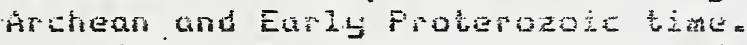

Faiporift systens are frirged by linear collision zones irampi- the pesuliar sinal-scalz subduction areas compensating the paleorif tension. Juring their short-berm impuse opening tue to decupression these zones were injected by

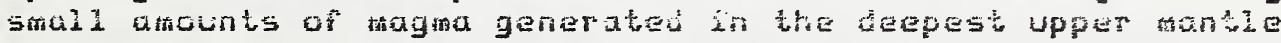

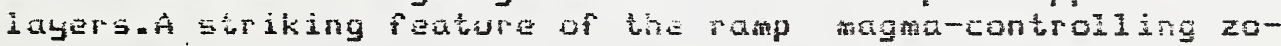
nes was hiat their 5 and areas ancomadated numerous kithberitie ucties of tifferent age.

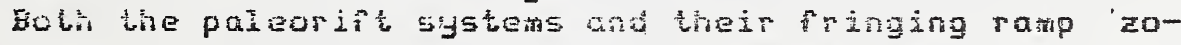
nes have dtiferen characterisides of the deep structure The paleorift systems carrespond to tome-like uplifts in the theho discontinuity (with an amplitude up to 8 kn) and reduction in crustal thickness up to $32-34$ kh due to wedging out of the upper velocity dayers. Seismic sourding also reveals a high degree of layering of the lowiar veldeity level $6.8-7.0$ $\mathrm{km} / \mathrm{s}$, and the upper tantle. This als be interpresed as reiics of ancient destruction resuiting from piftogenim tension and mantle degassing.

Absence of correlation betwer the gravimagnetic field anomalies has been reperted for the collision/ramp/ zones located as faras $150-200 \mathrm{~km}$ away from the paleorift axes.

Detailed seismic studies conducted by V.l. Suvorov allowed to identify the ramp zories in the lowermost crustal layers by the dramatic increase in the boundary velocities (up to $9.1 \mathrm{~km} / \mathrm{s}$ ), the appearance of $8-12 \mathrm{~km}$ deep trenches in the Moho discontinuity, the anticlinal uplifts at the intracrustal K-reflection boun-darys higher foissanys ratio and higher absorption of resillent waves due to increased compression and significant growth of mass exchunge. 
The paleoriôt areas usually correspond bo she platîn Lover, sbreclises while the ramp zones arz desocioted with

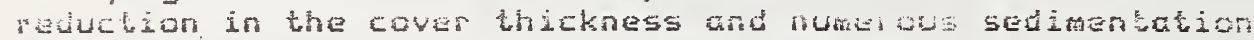
gus s.

The classtcal kimberitue fields tend bo bosociated with areas of intercrossing of ratp zand and Las Frecambiar -

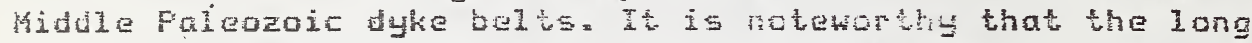

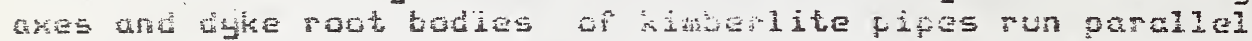
to the trend of ramp zones. This 3250 confirits the ragmacontroliting role of those regional dislocations.

Arother genetic group of da amoniferious rotis has been recogrized on the Siberian piatrorifo Is is represented by

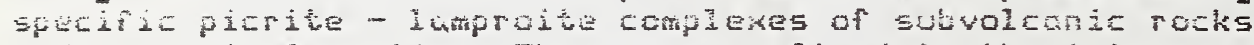
and voleanie formations. These are anfined to bhe intersection areas of paleorifi sututures and to shrike slio faults ef the transforth type. These complexes forthed sunchro-

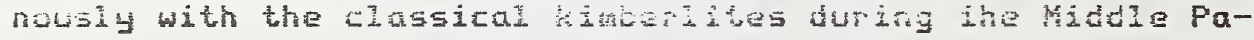

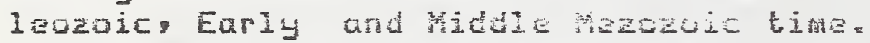

However, the conditon of ats gentrabion ir aransform zones differed frot those of hithorlite melt generation in

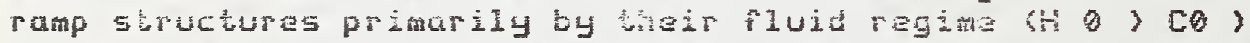
and by the tepth of wantie sources of atagm genteration. This

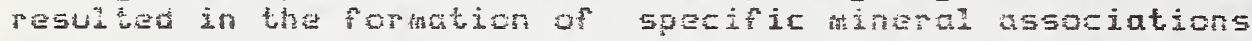
chiefly of the easogits and herzolitic parageneses and of

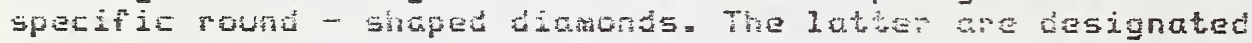

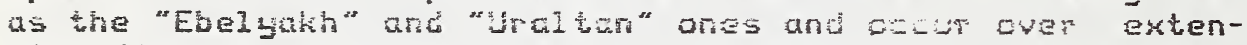

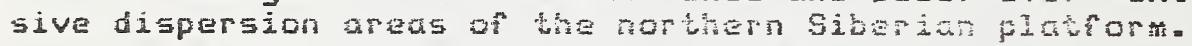

Hense the extension ant compressidn regites have been shouwn to combine in the considered tectonic enviroments. The difference 1 ies in the ret shut the cassical kimber-

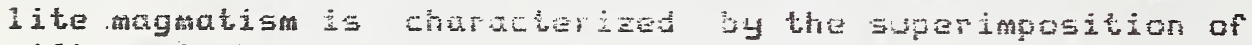
riftogenic branthes with basic dybe belts on the collision (ramp) zones while the piertio-1anploibe complexes feature the reverse picturey i.e the "iftogenis "shots" resulLng frot extension are crosed by strike sip fault zo-

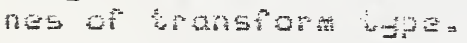

